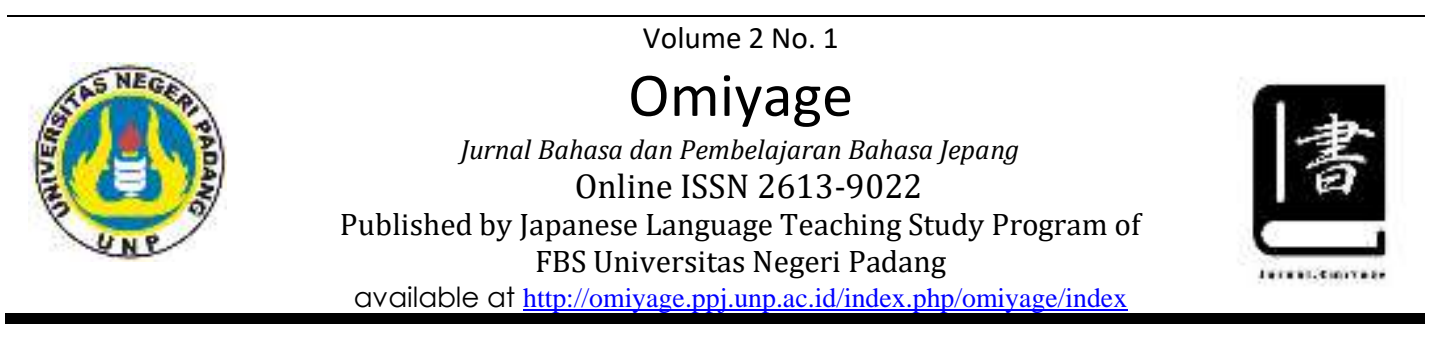

\title{
EFEKTIVITAS PENGGUNAAN KAHOOT TERHADAP PENGUASAAN GOI SISWA KELAS X SMA NEGERI 4 PADANG
}

\author{
Azola Minata ${ }^{1}$, Damai Yani ${ }^{2}$ \\ 1 (Mahasiswa Pendidikan Bahasa Jepang, Bahasa dan Sastra Inggris, Fakultas Bahasa dan \\ Seni, Universitas Negeri Padang) \\ 2 (Dosen Pendidikan Bahasa Jepang, Bahasa dan Sastra Inggris, Fakultas Bahasa dan Seni, \\ Universitas Negeri Padang) \\ Email Penulis: azolaminata@gmail.com
}

\begin{tabular}{lr}
\hline Sejarah Artikel \\
\hline Submit $\quad: 2019-07-19$ \\
Diterima $:$ 2019-07-19 \\
Diterbitkan : 2019-08-30
\end{tabular}

\section{Kata Kunci:}

Goi, Kahoot, effectiveness

\begin{abstract}
Abstrak
This research is backed by the lack of goi mastery in students. This is because the exercises in the learning process are still less varied, one example of exercises that can be used is Kahoot. This study aims to determine the effectiveness of Kahoot on the mastery of goi class $X$ SMA Negeri 4 Padang. This study used a quantitative approach with a pseudo-experimental "posttest only control group design" method. The population in this study is a class X SMA Negeri 4 Padang which is registered in the period of JanuaryJuly 2018/2019 school year. The research sample is 32 students in grade X MIPA 6 as an experimental class and 33 students in grade X IIS 1 as a control class. This research data is the final test score of goi mastery without and by the use of kahoot grade X SMA Negeri 4 Padang. The test results were compared to usingthe test- $t$ formula to determine the effectiveness of kahoot mastery of goi. Based on test-t results, it was concluded that the learning to use kahoot significantly effectively on the mastery of goi in grade X students of SMA Negeri 4 Padang because $T$ count $>$ T table $(5.21>2.00)$ at a significant level of 0.05. So, it was concluded that the governance of the goi class X SMA Negeri 4 Padang by using kahoot is better than without using kahoot.
\end{abstract}

\section{PENDAHULUAN}

Bahasa merupakan alat untuk menyampaikan gagasan, pikiran, pendapat dan perasaan. Untuk itu bahasa sangat penting bagi kehidupan manusia, terutama sebagai alat komunikasi. Bahasa yang diajarkan saat berada di bangku sekolah terdapat bahasa ibu dan bahasa asing. Saat sekarang ini selain bahasa Indonesia yang merupakan bahasa ibu, masyarakat juga mempelajari beberapa bahasa asing, salah satunya yaitu bahasa Jepang. 
Menurut Alim (2014:2) di antara bahasa-bahasa asing yang diajarkan adalah bahasa Jepang. Dalam sejarah bangsa Indonesia, sesungguhnya bahasa Jepang sudah pernah diajarkan oleh tentara Jepang pada masa pendudukan Jepang dahulu. Meskipun belum diajarkan secara terencana di bangku sekolah, tetapi setiap orang yang sudah pernah belajar, mereka berkewajiban mengajarkannya lagi kepada orang lain.

Salah satu aspek yang sangat penting dalam pembelajaran bahasa Jepang adalah kosakata (Goi). Hal ini sesuai dengan pendapat Yuriko dalam Sudjianto (2009:97) bahwa penguasaan goi yang memadai adalah faktor penunjang untuk berkomunikasi baik secara lisan maupun tulisan. Tujuan komunikasi bisa tercapai apabila pembelajar bahasa Jepang bisa mengungkapkan pendapatnya secara lisan dan tulisan.

Guru dapat memanfaatkan perkembangan ilmu pengetahuan dan teknologi untuk menciptakan pembelajaran goi yang menarik dan menyenangkan. Selain menciptakan suasana yang menyenangkan guru dapat menggunakan media yang menarik saat melakukan proses pembelajaran sebagai upaya dalampenguasaan goi yang dilihat melalui hasil belajar. Hasil penelitian yang dilakukan

oleh Irawati (2018) menunjukkan bahwa pembelajaran dengan menggunakan media Kahoot menunjukkan hasil yang baik terhadap hasil belajar siswa. Dengan demikian Kahoot merupakan salah satu media berupa kuis yang diharapkan dapat digunakan untuk meningkatkan hasil belajar siswa dalam pembelajaran goi.

Menurut penelitian yang dilakukan oleh Irawati (2018) yang berjudul "Profil Minat dan Hasil Belajar Siswa Dalam Pembelajaran Matematika Kelas VIII SMP Negeri 5 Yogyakarta Pada Pokok Bahasan Penyajian Data Dengan Menggunakan Media Pembelajaran Kahoot" menyimpulkan bahwa pembelajaran dengan menggunakan media kahoot dapat meningkatkan minat belajar dan hasil belajar siswa.

Peneliti memilih SMA Negeri 4 Padang sebagai tempat penelitian ini dikarenakan rendahnya penguasaan goi dan kurang variatifnya latihan dalam proses pembelajaran bahasa Jepang. Hal tersebut dibuktikan berdasarkan pengamatan dan pengalaman peneliti selama menjalankan praktik lapangan kependidikan di SMA Negeri 4 Padang dari hasil ujian semester satu terdapat $50 \%$ soal ujian mengenai goi, hampir $75 \%$ siswa kelas X terkategorikan belum memenuhi batas KKM yaitu 80. Dan kurang variatifnya latihan yang dilakukan dalam proses pembelajaran bahasa Jepang, guru hanya menggunakan latihan pada buku sakura jilid 1. Dengan adanya Kahoot diharapkan guru dapat melakukan latihan setiap memulai atau pada akhir pembelajaran, sehingga guru dan peserta didik dapat melihat langsung penguasaan materi yang di pelajari pada hari itu ataupun pada pertemuan sebelumnya.

Dari uraian diatas, penulis memilih Kahoot untuk diujicobakan dalam penelitian penguasaan goi di kelas X IIS 1 dan X MIPA 6 SMA Negeri 4 Padang. Dikarenakan berdasarkan pengalaman selama praktik lapangan kependidikan kedua kelas ini kurang menguasai goi dan ketika disertakan media dalam proses pembelajaran kedua kelas ini lebih bersemangat untuk 
belajar. Kahoot sendiri belum pernah digunakan dalam proses pembelajaran bahasa Jepang di SMA Negeri 4 Padang. Sehingga dengan digunakannya Kahoot dalam proses pembelajaran diharapkan dapat meningkatkan penguasaan goi.

Mahasiswa Prodi Pendidikan Bahasa Jepang FBS UNP lulus pada tanggal September 2019

2 Dosen Prodi Pendidikan Bahasa Jepang FBS UNP

\section{METODE PENELITIAN}

Jenis penelitian ini adalah penelitian kuantitatif. Menurut Sugiyono (2017:8) penelitian kuantitatif dapat diartikan sebagai metode penelitian yang berlandaskan pada filsafat positivisme, digunakan untuk meneliti pada populasi atau sampel tertentu, pengumpulan data menggunakan instrumen penelitian, analisis data bersifat kuantitatif/statistik, dengan tujuan untuk menguji hipotesis yang telah ditetapkan. Metode penelitian ini adalah metode eksperimen. Jenis eksperimen ini adalah quasi eksperimen (eksperimen semu). Menurut Sugiyono (2017:77) eksperimen semu merupakan pengembangan dari true experimental desain, yang sulit dilaksanakan. Desain ini mempunyai kelompok kontrol, tetapi tidak dapat berfungsi sepenuhnya untuk mengontrol variabel-variabel luar yang mempengaruhi pelaksanaan eksperimen. Desain penelitian ini adalah posttest onlycontrol group design. Menurut Arikunto (2010:212) desain ini adalah desain yangmenggunakan sekelompok subjek penelitian dari suatu populasi tertentu, kemudian dikelompokkan menjadi dua kelompok kelas, yaitu kelas eksperimen dan kelas kontrol. Dalam penelitian ini kelompok eksperimen diberi perlakuan menggunakan Kahoot sedangkan kelompok kontrol diberi perlakuan menggunakan metode konvensional.

Populasi dalam penelitian ini adalah siswa kelas X SMA Negeri 4 Padang. Siswa kelas X di SMA Negeri 4 Padang yang mempelajari bahasa Jepang hanya 5 kelas yang berjumlah 164 orang. Teknik penarikan sampel yang digunakan dalam penelitian ini adalah purposive sample atau sampel tujuan. Purposive sample adalah teknik penentuan sampel dengan pertimbangan tertentu. Mengambil teknikpurposive sample karena berdasarkan pengalaman praktik lapangan kependidikan, penulis memilih SMA Negeri 4 Padang cocok untuk dijadikan sampel penelitian. Sampel dalam penelitian ini adalah 33 orang siswa kelas X MIPA 6 sebagai kelas eksperimen dan 33 orang siswa kelas X IIS 1 sebagai kelas kontrol.

Instrumen yang digunakan dalam penelitian ini adalah tes. Menurut Masidjo (1995:38) tes adalah suatu alat pengukur yang berupa serangkaian pertanyaan yang harus dijawab secara sengaja dalam suatu situasi yang distandardisasikan, dan yang dimaksudkan untuk mengukur kemampuan dan hasilbelajar individu atau kelompok. Dalam hal ini, tes hasil penguasaan goi dengan menggunakan Kahoot.

Tahapan pelaksanaan dalam penelitian ini pertemuan pertama, menjelaskan goi menggunakan Kahoot kepada siswa dan melaksanakan treatment satu. Pertemuan kedua, melaksanakan treatment dua. Pertemuan ketiga, melaksanakan treatment tiga. Treatment pada kelas eksperimen dalam penguasaangoi dilakukan dengan Kahoot. Sedangkan treatment pada kelas kontrol tanpamenggunakan Kahoot. Dan pertemuan 
keempat, melaksanakan tes akhir (posttest)oleh siswa.

\section{HASIL DAN PEMBAHASAN}

Deskripsi data dalam penelitian ini adalah hasil yang diperoleh dari tes penguasaan goi yang diberikan pada kelas sampel. Soal tes akhir berupa objektif 20 butir. Tes penguasaan goi diikuti oleh 32 orang siswa kelas eksperimen dan 33 orang kelas kontrol. Setelah tes dikumpulkan, dilakukan penskoran. Tahap selanjutnya adalah mengubah skor menjadi nilai. Setelah itu dilakukan perhitungan nilai maksimal, nilai minimal, modus, median, rata-rata dan standar deviasi yang dapat dilihat pada tabel berikut ini.

\begin{tabular}{cccc}
\hline No & Perhitungan & Kontrol & Eksperimen \\
\hline 1 & Nilai Maksimal & 95 & 100 \\
\hline 2 & Nilai Minimal & 60 & 75 \\
\hline 3 & Modus & 85 & 100 \\
\hline 4 & Median & 77,5 & 87,5 \\
\hline 5 & Rata-rata & 81,06 & 92,50 \\
\hline 6 & Simpangan Baku & 8,91 & 6,72 \\
\hline
\end{tabular}

Berdasarkan tabel di atas, dapat dilihat nilai rata-rata kelas eksperimen lebih tinggi dari kelas kontrol yang membuktikan bahwa kemampuan siswa kelas eksperimen secara umum lebih baik dari siswa kelas kontrol. Nilai maksimal pada kelas eksperimen lebih tinggi dibandingkan dengan kelaskontrol, sedangkan nilai minimal kelas kontrol lebih rendah dibandingkan dengan kelas eksperimen. Modus dan median pada kelas eksperimen lebih tinggi dibandingkan dengan kelas kontrol. Standar deviasi posttest kemampuan goi pada siswa kelas eksperimen lebih kecil dibandingkan dengan siswa kelas kontrol. Hal ini menunjukkan bahwa nilai posttest kelas eksperimen lebih relatif sama dan mendekati rata-rata dibanding kelas kontrol yang lebih beragam.

Berdasarkan hasil penelitian, untuk indikator 1 (Mampu Mengidentifikasi Kata Sesuai Arti) diperoleh rata-rata hitung penguasaangoi pada siswa kelas X SMA Negeri 4 Padang tanpa menggunakan kahoot pada kelas kontrol sebesar 85,45. Jika nilai rata-rata tersebut dibandingkan dengan Kriteria Ketuntasan Minimal (KKM) kelas X SMA Negeri 4 Padang

untuk mata pelajaran bahasa Jepang adalah 80, maka penguasaan goi pada siswa kelas kontrol sudah memenuhi KKM dengan kategori baik.

Untuk indikator 2 (Mampu Mengidentifikasi Kata Berdasarkan Gambar) 
diperoleh rata-rata hitung penguasaan goi pada siwa kelas X SMA Negeri 4 Padang tanpa menggunakan kahoot pada kelas kontrol sebesar 76,67. Jika nilai rata-rata tersebut dibandingkan dengan KKM mata pelajaran bahasa Jepang, maka penguasaan goi pada kelas kontrol belum memenuhi KKM. Hal ini disebabkan karena pengetahuan siswa tentang kosakata yang sesuai dengan gambar masih terbatas.

Selanjutnya, untuk indikator 1 (Mampu Mengidentifikasi Kata Sesuai Arti) perolehan rata-rata hitung penguasaan goi pada siswa kelas X SMA Negeri 4 Padang dengan menggunakan kahoot pada kelas eksperimen untuk indikator 1 sebesar 92,42. Jika nilai rata-rata tersebut dibandingkan dengan KKM mata pelajaran bahasa Jepang, maka penguasaan goi pada siswa kelas eksperimen sudah di atas KKM dengan kategori baik sekali. Hal ini disebabkan setelah pembelajaran goi siswa mengingat kembali kosakatayang telah dipelajari pada latihan dengan menggunakan kahoot yang nantinya dapat memotivasi siswa untuk menghafal kosakata tersebut agar mendapatkan nilai tertinggi.

Untuk indikator 2 (Mampu Mengidentifikasi Kata Berdasarkan Gambar) perolehan rata-rata hitung penguasaan goi pada siwa kelas X SMA Negeri 4 Padang dengan menggunakan kahoot pada kelas eksperimen untuk indikator 2 sebesar 89,69. Jika nilai rata-rata tersebut dibandingkan dengan KKM mata pelajaran bahasa Jepang, maka penguasaan goi pada siswa kelas eksperimen sudah memenuhi KKM dengan kategori baik sekali. Hal ini disebabkan dalam pembelajaran goi menggunakan kahoot, siswa disuruh menebak kosakata yang ditampilkan pada kahoot yaitu berupa gambar yang berhubungan dengan kosakata yang telah dipelajari. Sehingga kosakata sesuai dengan gambar tersebut dikuasai siswa dengan baik.

Berdasarkan hasil penilaian indikator 2 lebih rendah bila dibandingkandengan indikator 1 baik pada kelas kontrol maupun kelas eksperimen. Sedangkan hasil penilaian indikator 1 lebih tinggi bila dibandingkan dengan indikator 2 baik kelas kontrol maupun pada kelas eksperimen. Hal itu terjadikarena sebagian besar soal pada indikator 2 berada pada tingkat kesukaran yang sedang. Sedangkan sebagian besar soal pada indikator 1 berada pada tingkat kesukaran yang lemah. Hal tersebut dapat dibuktikan dari hasil analisis butir soal pada uji coba soal yang telah dilakukan.

Berdasarkan hasil tes yang diperoleh dari nilai rata-rata perindikator, nilai ratarata kelas eksperimen pada indikator 2 mengalami peningkatan yang signifikan bila dibandingkan dengan nilai rata-rata pada kelas kontrol. Hal tersebut terjadi dikarenakan pada kelas eksperimen menggunakan kahoot sebagai latihan. Pada kahoot siswa dapat mengingat kosakata menggunakan gambar, yang dimana sebagian besar siswa lebih mudah memahami ataupun mengingat suatu pembelajaran apabila disertai gambar.

Berdasarkan hasil tes yang diperoleh dari nilai rata-rata perindikator, nilai kelas 
eksperimen lebih baik dibandingkan kelas kontrol seperti yang telah dijelaskan sebelumnya. Secara umum nilai akhir setelah pemberian perlakuan dengan menggunakan kahoot di kelas eksperimen dan pembelajaran konvensional di kelas kontrol, diperoleh rata-rata hasil belajar kelas eksperimen (X MIPA 6) adalah 92,50 dengan standar deviasi (S) 6,72. Sementara rata-rata nilai kelas kontrol (X IIS 2) adalah 81,06 dengan standar deviasi (S) 8,91. Dari hasil rata-rata nilai kelas eksperimen dan kelaskontrol terlihat bahwa nilai rata-rata kelas eksperimen lebih baik dibandingkan dengan nilai rata-rata kelas kontrol. Sehingga dari analisis data akhir menunjukkan bahwa diperoleh $t$ hitung $=5,21$ sedangkan $t$ tabel $=2,00$. Karena $\mathrm{t}$ hitung $>\mathrm{t}$ tabel $(5,21>2,00)$ maka signifikan dan hipotesis yang diajukan oleh peneliti dapat diterima. Ini berarti nilai rata-rata hasil belajar pada kelas eksperimen lebih baik atau tidak sama dengan hasil belajar kelas kontrol. Keberhasilan proses pembelajaran juga tidak terlepas dari peningkatan intensitas keterlibatan siswa secara efektif di dalam proses pembelajaran. Pengembangan latihan yang tepat pada dasarnya bertujuan untuk menciptakan kondisi pembelajaran yang memungkinkan peserta didikdapat belajar secara aktif dan menyenangkan sehingga peserta didik dapat meraih hasil belajar dan prestasi yang optimal.

Ketika semua proses di atas telah dilakukan, maka peserta didik dapat menguasai apa yang telah mereka pelajari. Kondisi ini yang menyebabkan hasil belajar siswa kelas eksperimen lebih tinggi dari pada hasil belajar siswa kelas kontrol. Sehingga penggunaan kahoot pada materi goi berpengaruh terhadap hasil belajar siswa kelas X SMA Negeri 4 Padang. Hal ini dilihat dari hasil rata-rata nilai kelas eksperimen 93,38 dan di kelas kontrol 84,45. Hal ini menunjukkan bahwa penggunaan kahoot berdampak positif terhadap hasil belajar siswa.

Dalam penelitian ini ditemukan faktor yang mempengaruhi proses belajar siswa, yaitu yang berasal dari dalam diri siswa itu sendiri yang berupa minat dan motivasi. Minat yang besar pengaruhnya terhadap belajar. Bahkan pelajaran yang menarik minat siswa akan lebih mudah dipahami dandisimpan. Setelah digunakan kahoot dalam proses pembelajaran, motivasi siswa dalam mempelajari mata pelajaran bahasa Jepang lebih meningkat. Buktinya dilihat dari semangat mereka yang berusaha mengingat kosakta yang dipelajari agar mendapat nilai tertinggi saat melakukan latihan dengan menggunakan kahoot. Selain itu antusias mereka juga dapat dilihat dari semangat dalam belajar dan latihan dengan menggunakan kahoot yang menarik dan berbeda bagi siswa tersebut. Sesuai dengan teori dan kajian pustaka yang digunakan penulis, hasil penelitian ini menunjukkan bahwa penggunaan kahoot efektiv terhadap pembelajaran kosakata siswa kelas X SMA Negeri 4 Padang.

Kemudian, jika dibandingkan dengan penelitian terdahulu mengenai penggunaan kahoot, dilihat dari penelitian yang dilakukan oleh Irawati (2018) yang meneliti tentang Profil Minat dan Hasil Belajar Siswa Dalam Pembelajaran Matematika Kelas VII I SMP Negeri 5 Yogyakarta PadaPokok Bahasan Penyajian Data Dengan 
Menggunakan Media Pembelajaran Kahoot. Dalam penelitian Irawati menyimpulkan bahwa pembelajaran dengan menggunakan media Kahoot dapat meningkatkan minat belajar dengan rata-rata persentase peningkatan sebesar 8,36\% ditinjau dari angket. Sedangkan analisis hasil belajar siswa dengan menggunakan Kahoot dalam kategori baik dan meningkaat. Hal ini ditunjukkan pada analisis belajar siswa yaitu persentase banyaknya siswa yang tuntas pada pelaksanaan post test yaitu 66,67\%. Dalam penelitian ini, penggunaan Kahoot juga efektiv terhadap penguasaan goi siswa kelas X SMA Negeri 4 Padang. Hal ini ditunjukkan pada analisis belajar siswa yaitu persentase banyaknya siswa yang tuntas pada pelaksanaan post test kelas eksperimen yaitu $96,87 \%$. Berdasarkan analisis data akhir menunjukkan bahwa diperoleh thitung $=5,21$, sedangkan $\mathrm{t}$ tabel $=2,00$. Karena $\mathrm{t}$ hitung $>\mathrm{t}$ tabel $(5,21>2,00)$ maka signifikan dan hipotesis di terima. Hal tersebut menunjukkan bahwa penggunaan Kahoot efektiv terhadap penguasaan goi siswa kelas X SMA Negeri 4 Padang. Dengan demikian, dapat disimpulkan bahwa penggunaan kahoot tidak hanya meningkatkan minat dan hasil belajar yang signifikan terhadap hasil belajar matematika saja, namun juga efektiv dan memberikan peningkatan yang signifikan terhadap penguasaan goi.

\section{KESIMPULAN}

Berdasarkan hasil penelitian, disimpulkan beberapa hal berikut. Penguasaan goi pada siswa kelas X SMA Negeri 4 Padang dengan menggunakan kahoot berada pada kualifikasi baik sekali dengan nilai rata- rata 92,50, dan tanpa menggunakan kahoot berada pada kualifikasi baik dengan nilai rata-rata 81,06. Berdasarkan standar Kriteria Ketuntasan Minimal (KKM) yang digunakan pada SMA Negeri 4 Padang yaitu 80. Persentase siswa yang memperoleh nilai di atas KKM dari kelas kontrol tanpa menggunakan kahoot yaitu $72,73 \%$ dan di bawah KKM sebanyak $27,27 \%$. Sedangkan, persentase siswa yang memperoleh nilai di atas KKM dari kelas eksperimen dengan menggunakan kahoot yaitu 96,87\% dan di bawah KKM sebanyak $3,13 \%$. Pembelajaran bahasa Jepang berpengaruh secara signifikan terhadap penguasaan goi pada siswa kelas X SMA Negeri 4 Padang karena dengan menggunakan kahoot siswa lebihtermotivasi dalam belajar dan mampu menguasai goi. Jadi, disimpulkan bahwa penguasaan goi siswa kelas X SMA Negeri 4 Padang dengan menggunakan kahoot lebih baik dari pada tanpa menggunakan kahoot.

Berdasarkan hasil uji-t disimpulkan bahwa terdapat pengaruh yang signifikan dari penggunaan kahoot terhadap penguasaan goi siswa kelas X SMA Negeri 4 Padang karena $t_{\text {hitung }}$ besar dari $t_{\text {tabel }}(4,85>2,00)$. Jadi dapat disimpukan bahwa penguasaan goi siswa kelas X SMA Negeri 4 Padang dengan diberi perlakuan menggunakan kahoot lebih baik dari pada tanpa menggunakan kahoot. Hal tersebut menunjukkan bahwa penggunaan kahoot efektiv pada pembelajaran goi siswa kelas X SMA Negeri 4 Padang.

Berdasarkan kesimpulan yang diperoleh dari hasil penelitian, maka dikemukakan saran-saran berikut. Bagi siswa diharapkan selalu aktif dalam mengikuti kegiatan pembelajaran khususnya goi sehingga dapat menghasilkan 
pengetahuan yang bersifatkomprehensif baik afektif, psikomotor, dan kognitif serta mempersiapkan materi yang akan dipelajari terlebih dahulu. Selanjutnya, bagi guru untuk mewujudkan tujuan pembelajaran, disarankan kepada guru mata pelajaran bahasa Jepang untuk menerapkan penggunaan kahoot dalam pembelajaran khususnya goi. Hal tersebut bertujuan untuk menciptakan suasana belajar yang menyenangkan serta menarik perhatian siswa dalam belajar. Dan kemudian, bagi peneliti lain diharapkan berikutnya yang melakukan penelitian sejenis mengenai penggunaan kahoot dalam pembelajaran lain pada bahasa Jepang seperti hiragana, katakana, kanji, dokkai, kaiwa, bunpo, choukai, dan sakubun, sehingga dapat menggunakan penelitian ini sebagai referensi untuk memperkuat sintesa teori serta lebih mengkolaborasikannya agar lebih menarik.

\section{REFERENSI}

Alim, Burhanuddin. (2014). Ayo Belajar Bahasa Jepang. Yogyakarta: Graha Ilmu.

Arikunto, Suharsimi. (2010). Prosedur Penelitian: Suatu Pendekatan Praktik. Yogyakarta: PT. Asdi Mahasatya.

Irawati, Magdalena. (2018). Profil Minat dan Hasil Belajar Siswa Dalam Pembelajaran Matematika Kelas VII I SMP Negeri 5 Yogyakarta PadaPokok Bahasan Penyajian Data Dengan Menggunakan Media Pembelajaran Kahoot. Skripsi. Yogyakarta: Universitas Sanata Dharma.

Mardianti, Yosla. (2018). Pengaruh Metode Pembelajaran Student Teams Achievement Divisions (STAD) terhadap Penguasaan Goi (Goi) Siswa KelasX SMA Negeri 12 Padang. Skripsi. Padang: Universitas Negeri Padang.

Masidjo.(1995). Penilaian Pencapaian Hasil BelajarSiswa di Sekolah. Yogyakarta: Kanisius.

Sudjianto dan Dahidi. (2009). Pengantar Linguistik Bahasa Jepang. Bandung: Kesaint Blanc.

Sugiyono. (2017). Metode Penelitian Kuantitatif, Kualitatif, dan R\&D. Bandung: Alfabeta. 